\title{
Perceptions of Macro Social Work Education: An Exploratory Study of Educators and Practitioners
}

\author{
Katharine M. Hill \\ Christina L. Erickson \\ Linda Plitt Donaldson \\ Sondra J. Fogel \\ Sarah M. Ferguson
}

\begin{abstract}
Social work graduate education is responsive to and reflective of larger environmental forces, including economic and job market trends, regulations by diverse organizations, and student interests. A national online survey of macro social work educators $(n=208)$ and macro social work practitioners $(n=383)$ explored their perceptions of the intersections between these forces and graduate social work education. Findings indicate that while there remains a consistent level of support for and inclusion of macro social work within MSW programs from both groups, macro practitioners identified a concurrent experience of negative perceptions, attitudes, and experiences toward macro social work education while in their graduate programs. We suggest that social work programs seek out opportunities to integrate macro practice content and field experiences into their curriculum, so that students can be better equipped to respond to the complex systemic challenges they will encounter while in professional practice.
\end{abstract}

Keywords: Social work education; social work licensure; macro social work

Macro practice is defined as social work practice with larger systems, such as communities, human service agencies, or public policy environments. CSWE indicates that the number of macro social work MSW graduates (inclusive of policy, administration, and organizing) has been consistent over the past twenty years at less than $10 \%$ of all MSW students (CSWE, 2015b, 2016). Despite this, there have been growing concerns about the decline in the number of social work students with specialized macro knowledge and skills (Fisher \& Corciullo, 2011). In 2013, the Special Commission to Advance Macro Practice was formed to give focused attention to strengthening and advancing macro practice concentrations/specializations and curricula throughout CSWE-accredited programs (Association for Community Organization and Social Administration [ACOSA] 2017). This exploratory study investigated the impact of internal and external factors on macro practice in social work graduate education as perceived by faculty and practitioners specializing in this area.

Social work practice and education responds to and reflects the larger social, cultural, and political environments (Lein, Uehara, Lightfoot, Lawlor, \& Williams, 2017). Since its

\footnotetext{
Katharine Hill, MSW, MPP, PhD is an Associate Professor at the School of Social Work at St. Catherine University and the University of St. Thomas in St. Paul, MN. Christina Erickson, MSW, PhD, is an Associate Professor in the Department of Social Work at Augsburg College in Minneapolis, MN. Linda Plitt Donaldson, MSW, PhD is an Associate Professor at Catholic University, National Catholic School of Social Service in Washington, DC. Sondra Fogel, MSW, PhD is an Associate Professor in the School of Social Work at the University of South Florida in Tampa, FL. Sarah Ferguson, MA, MSW, PhD is Associate Vice President of Academic Affairs and Academic Dean at Saint Mary's University in Minneapolis, MN.

Copyright ( 2017 Authors, Vol. 18 No. 2 (Fall 2017), 522-542, DOI: 10.18060/21455 (cc) BY This work is licensed under a Creative Commons Attribution 4.0 International License.
} 
very earliest roots in both Charity Organization Societies and the Settlement House movement (Lubove, 1977; Wenocur \& Reisch, 1989), social work education has been influenced by several societal factors. The first is faculty expertise and competing practice orientations such as scientific casework, group work, community organization, and policy practice. The second includes those organizations that regulate educational content and practice. The Council on Social Work Education (CSWE, 2015a) Commission on Accreditation develops educational standards that define competent social work practice at both the undergraduate and graduate levels and administers an accreditation process to ensure compliance with those educational standards. Another important influence on social work education includes state licensure standards and the Association of Social Work Boards (ASWB) which develops multiple social work licensing exams to reflect various social work degrees and specializations (i.e., BSW Generalist, MSW Generalist, MSW Clinical). The academic environment of social work programs, as well as students' expectations for their social work education and professional trajectories, also play a role in the implicit activities that promote educational content. Finally, third-party reimbursement and employer hiring practices shape how social work opportunities are framed in the job market. Taken together, these factors influence the profession in numerous, interrelated ways.

\section{Literature Review}

In 2014, Rothman and Mizrahi explicitly called for rebalancing social work education and field components with macro social work content, noting a clinical content dominance in these areas. These scholars argue that despite the historical emphasis on both the individual and community, micro and macro practice, our professional Code of Ethics, and numerous professional organizations representing macro practice, the profession is "preponderantly weighted toward clinical practice" (p. 92). Data supports this. The number of graduate social workers with a clinical license dominates the professional landscape, as approximately 93\% of post-MSW licensee's hold a clinical license (Donaldson, Hill, Ferguson, Fogel, \& Erickson, 2014). Earlier, we suggested that there are interrelated factors that have worked to create this dynamic. Examples follow.

\section{Faculty Orientation}

Debates about the place of macro practice in social work have been present in the literature and in the academy for decades (Ezell, Chernesky \& Healy, 2004; Hill, Ferguson, \& Erickson, 2010; Miller, Tice, \& Hall, 2008; Pine \& Healy, 1994). In 2012, ACOSA commissioned a study of their academic membership to better understand the state of macro practice in social work education programs. Based on this study, Rothman (2012) identified a number of factors that contributed to faculty concerns about macro social work education. Among those factors were: lack of faculty interest in or understanding of macro practice, the marginalization of macro courses, declining curriculum space and field placement opportunities among clinically-structured programs, students being discouraged from selecting a macro concentration, and clinical social work licensing driving curricular decisions. One respondent wrote, "[Clinically-bounded] licensure is the death of macro practice and is tragic for the future of social work" (p. 9). These results suggest that 
graduate social work curricula may favor educational content reflective of state licensing options, even if this is an unintentional outcome (Miller, Deck, Grise-Owens, \& Borders, 2015). Fogel and Ersing (2016) note that there has been a decline in completed social work dissertations with a focus on macro practice, and suggest that this decline may be related to fewer faculty members interested in and prepared to teach this content within schools of social work, an area that warrants further study.

\section{Regulatory Organizations}

Most states have laws that require that graduates of MSW programs achieve stateregulated licensure in order to practice as a social worker,. For the purpose of this article, the term "license" refer to those types of licenses that are available as options for MSW graduates. The universal qualifier for social work licensing in the United States is for individuals to attain a social work degree from a CSWE-accredited program and pass a licensing exam. Most of these State laws are modeled after the Association for Social Work Board's (ASWB) Model State Social Work Practice Act (Bibus \& Boutté-Queen, 2011).

Various types of social work licenses are available for post-MSW students depending on professional experience, interest, and state board criteria. The types of licenses available vary from state to state. In addition, states have a variety of additional requirements for the types of licensure they offer (Donaldson et al., 2014). Indeed, some states have moved to include specific MSW curricular content for advanced clinical social work licensure. Required content that some states include is related specifically to clinical diagnoses and interventions and require field placements in clinical settings where students gain experience in clinical diagnosis and methods of treatment and intervention (Donaldson et al., 2014). As State board requirements have become more specific, some schools have moved to ensure that their students, who will need the licensing credential to practice, have the requisite clinical coursework during their MSW program (Miller et al., 2015). Thus, curricula have shifted in response to State board requirements, which in turn, are responding to workforce trends and/or legislative requirements.

State board mandates for these additional requirements vary from state to state, limiting social workers' ability to move among states and qualify for the same license. For example, a social worker may be licensed as a clinical social worker in one state but may be ineligible in the next state due to these expanded curriculum requirements, even though the student has passed the clinical exam and graduated. Scholars have raised questions about the fit between content covered in licensure exams and content that is taught as part of the MSW curriculum (Black \& Whelley, 1999; Cherry, Rothman, \& Skolnik, 1989; Strom \& Gingerich, 1993). Biggerstaff (2000) identified multiple concerns with increased public regulation of social work practice, including the limitation of practice to "...certain theoretical and practice perspectives...” (p. 112) which are included in the statutory language, as well as the possibility that statutory language may limit the scope of practice, to the deficit of "...practice, future technological development and knowledge expansion...” (p. 111). There seems to be consensus that licensing requirements do, in fact, influence both social work practice and social work education (Boutté-Queen, 2003; Cherry et al., 1989; Ezell et al., 2004; Strom \& Gingerich, 1993; Wermeling, Hunn, \& McLendon, 2013). However, there is scant literature about how schools of social work 
specifically implement and infuse curricula content to help students pass licensing exams (Miller, Grise-Owens, \& Esobar-Ratliff, 2015). Furthermore, the relationship between CSWE competencies/practice behaviors and the content on social work licensure exams has not yet been examined.

\section{Student Expectations}

Ezell and colleagues (2004) identified a number of challenges within social work education impacting student expectations after graduation including those in the implicit environment such as reports of social pressure from other students to select a clinical concentration, and negative attitudes among both students and faculty about macro practice and employability. Rothman (2012) identified similar challenges including a lack of interest from faculty in schools of social work regarding macro practice, shrinking faculty numbers in macro concentrations, and social work curriculums that were overwhelmingly focused on clinical practice. Difficulties with providing field practicum experiences for macro social work students have also been identified, such as a smaller number of placement opportunities and a lack of supervision for students in these types of placements (Mor Barak, Travis, \& Bess, 2004).

Challenges to student expectations regarding selecting a macro concentration that are external to social work graduate programs include opportunities for professional identity development and identification of macro social workers as field instructors and mentors (Hill et al., 2010; Lightfoot, Nienow, Moua, Colburn, \& Petri, 2016). When community practice social workers do not identify themselves professionally as social workers, the field loses role models and representation, both for other social workers and to other professions. Additionally, social workers who practice with larger systems are not always supported or well-represented within the profession (Moore \& Johnston, 2002; Weiss, 2003, 2006). For example, many positions that macro practice graduates may compete for, may not be identified as "social work" positions in the job title, description, or requirements. While social workers' knowledge, skills, and abilities may be an excellent fit for these positions, the positions may not be identified as specifically for social workers (Pritzker \& Applewhite, 2015).

Employment opportunities are also part of the context for current social workers and students. Market forces such as employment trends and third-party reimbursements as well as social trends and public policies have moved much of the profession towards a more clinical and micro direct-practice focus (Gibelman, 1999; Schneider \& Netting, 1999; Specht \& Courtney, 1994). Recent research suggests that graduate students are interested in obtaining their clinical social work license in order to increase their job opportunities and be recognized as a professional with specialized skills (Miller, Grise-Owens et al., 2015). Licensing implies that in order to have the "right to practice" (Kleiner \& Krueger, 2008, p. 1), it is necessary for individuals to have specific expertise. Thus, having a license indicates that the field has a “...specific skill applied to a specific function” (Lubove, 1977, p. 23).

As shown, there are many interrelated factors that influence content in social work education. As Reisch (2015) indicates, given the new sense of "urgency" regarding the 
plethora of social and global problems and the cultural divide (p. 2), the need for macro practice "has become increasingly apparent" (p. 3). The authors of this study sought to learn from macro practitioners and faculty about their experiences of macro social work education within schools of social work, the barriers and supports for a macro specialization, as well as the effect of external factors such as employment trends, public perceptions, and state licensing on this content area in social work curricula.

\section{Method}

Funded by a two-year grant from the New York Community Trust, this study draws from data collected as part of a larger exploratory study on licensing and graduate education in social work (Donaldson, Fogel, Hill, Erickson, \& Ferguson, 2016). A survey research design was used to collect both open and closed-ended responses from two distinct groups - faculty who teach macro courses in accredited social work programs (e.g., social policy, community organizing, international social development, nonprofit administration, etc.) and self-identified social work macro practitioners. Human subjects review and approval was obtained through the Institutional Review Board of the Catholic University of America.

Using a subset of the data collected in the larger project, this study explored following research questions:

1. What are the perceptions of macro practitioners and faculty of macro social work education?

2. What do macro faculty and practitioners identify as the internal and external influences on macro social work education?

\section{Sample}

Macro practitioner respondents. Identifying macro social workers can be difficult. Our first plan, to identify individuals through their licensure status (i.e., those with an advanced macro license) proved to be unsuccessful for several reasons. First, only three states offered an advanced macro license (Donaldson et al., 2014). Second, our collective professional knowledge told us that many macro social workers do not have an advanced license, and if they do, it is typically an advanced generalist license, not a macro license. Finally, many of the lists of licensed social workers did not differentiate among licensee types nor did they include e-mail information.

As an alternative, we ordered lists of social workers from the two state licensing boards (District of Columbia and Minnesota) that captured e-mail addresses and also differentiated between licensees. Neither of these offer an advanced macro license; rather, both areas offer an advanced generalist license (an LISW) as well as an advanced clinical license (LICSW). To supplement the list, we used a snowball sampling method to connect with macro social workers across the U.S., requesting they send out the survey via email to others. We also used snowball sampling methods to locate macro social workers without licenses, and posted notices on Facebook, LinkedIn and other social media sites and listservs inviting participation in the survey. In addition, we culled the contact information from the macro practitioners in the membership lists of ACOSA, the Network for Social 
Work Management, and the Social Welfare Action Alliance. This approach yielded 383 respondents. In order to identify their expertise in macro social work, practitioner respondents were provided with an overview and definition of macro social work practice, and then asked if they identified as macro social workers. If they self-identified their primary professional interest in one of these areas, they were asked to complete the survey.

Faculty Respondents. For our initial attempt to recruit a geographically diverse faculty sampling frame, we organized the list of CSWE-accredited schools by census region and randomly selected 15 schools from each of the four regions. Through online research and phone calls, we identified the faculty in those programs who taught macro courses, and gathered their contact information. In order to identify their expertise in macro social work, faculty respondents were provided with an overview and definition of macro social work practice, and then asked if they identified as macro social work faculty. Those who self-identified their primary academic interest in one of these areas were invited to complete the survey.

Because response rates from this first random sample were too low to be meaningful, we instituted a snowball sampling approach to increase participation. We sent the survey out through the MSW Education listserv to macro faculty colleagues and invited colleagues to forward it to other macro faculty. Additional sources we used included membership lists of the three primary macro-oriented social work associations: ACOSA, NSWM, and SWAA. These efforts increased the number of respondents to 208 educators.

\section{Survey Instrument}

The surveys were developed and distributed using Qualtrics, an online survey tool. The instrument development grew from a review of existing literature and from the authors' experiences as social work practitioners and academics. The faculty survey was pilot-tested with three faculty from CSWE-accredited MSW programs, and the practitioner survey was pilottested with four macro social work practitioners. The final surveys were made available in November 2012, and remained open until May of 2013.

The faculty survey consisted of four sections: 1) MSW program information, 2) barriers for student selection of macro concentration; 3) faculty attitudes toward licensing, and 4) faculty demographics. This article presents data from Sections 1, 2, and 4; data from section 3 were discussed in previous publications. Section one included seven questions about the macro components of their MSW program, e.g., whether or not they offered a macro concentration, average student enrollment in concentration, and whether the concentration is growing, stable, or declining. Section two included four questions related to faculty perceptions of student experiences in the MSW program, particularly as it related to selecting a macro concentration. This section included a list of items which respondents were asked to rank as barriers, from 0 (not at all important) to 100 (extremely important), in selecting a macro concentration or program. Barriers included licensing considerations, advice from peers, or the number of field placements available. Section 4 included seven demographic items (e.g., position, number of years at institution, age, gender, race).

The macro practitioner survey had five sections: 1) attitudes toward licensing, 2) licensure pursuit path, 3) experience in their MSW program, 4) professional macro practice and social work identity, and 5) demographics. This article presents findings from the third 
and fifth sections. Section three included four questions related to the practitioner's experience in their MSW program as a macro student: 1) did the program have a macrofocused concentration, 2) did the respondent choose the macro concentration, 3) six items related to school climate toward macro to which they responded yes or no (e.g., did they feel supported as a macro student, did they feel pressured to reconsider their choice in macro, did macro seem as important as micro practice, whether or not there was an emphasis on clinical social work), and 4) an open-ended question giving respondents an opportunity to share more about their MSW experiences.

\section{Data Analysis}

The survey results for faculty and practitioners were analyzed separately. Simple descriptive statistics, using SPSS software, were used for the quantitative data. For the open-ended responses, we followed the same approach that we had used in our larger study (Donaldson et al., 2016), pairing the open-ended responses with the closed-ended questions that immediately preceded them. In both surveys, the open-ended questions included in this analysis follow multiple closed-ended questions, and provide respondents with the opportunity to expand upon their responses. For example, in the faculty survey, the first open-ended question asks respondents to identify possible reasons for enrollment changes in their macro programs. This question follows five closed-ended questions about the history and health of macro social work education in their MSW program. Thus we chose to view the responses to the open-ended questions as a continuation of respondents' answers to the close-ended questions that immediately preceded them.

\section{Findings}

While exploratory, the findings of this study provide some insight into the state of the macro specialization in social work educational programs, faculty's perceptions of student's attitudes towards macro concentrations, and current practitioner's perceptions of their own macro practice education. This information provides some insight into how the social, cultural, and political contexts may be influencing macro social work practice.

\section{Participant Demographics}

Table 1 presents the demographic characteristics of the faculty and practitioner respondents. Fifty-one percent $(n=70)$ of faculty and $57.6 \%(n=175)$ of practitioners reported having an advanced level social work license. Of those who had a license, $71 \%$ $(n=34)$ of faculty and $22.4 \%(n=39)$ of practitioners reported having a clinical license, $21 \%$ $(\mathrm{n}=10)$ of faculty and $63.8 \%(\mathrm{n}=111)$ of practitioners had an advanced generalist license, and $8 \%(n=4)$ of faculty and $13.8 \%(n=24)$ of practitioners reported having a macro license. 
Table 1. Respondent Demographics

Average Age

Average Years in Social Work Average Years at Current Institution

Avg. Years in Macro Social Work

\begin{tabular}{cccc}
\multicolumn{2}{c}{ Faculty $(\mathrm{n}=208)$} & \multicolumn{2}{c}{ Practitioners $(\mathrm{n}=383)$} \\
$\mathrm{n}$ & $\overline{\mathrm{x}}$ & $\mathrm{n}$ & $\overline{\mathrm{x}}$ \\
\hline 91 & 53 & 172 & 46 \\
138 & 27.6 & 290 & 16 \\
138 & 12.7 & -- & -- \\
-- & -- & 138 & 11 \\
& & & \\
$\mathrm{n}$ & $\%$ & $\mathrm{n}$ & $\%$ \\
-- & -- & 212 & 68.2 \\
70 & 51 & 175 & 57.6 \\
34 & $71^{*}$ & 39 & $22.4^{* *}$ \\
10 & $21^{*}$ & 111 & $63.8^{* *}$ \\
4 & $8^{*}$ & 24 & $13.8^{* *}$ \\
\hline
\end{tabular}

Graduate Level License Advanced Level License Advanced Clinical License Advanced Generalist License Advanced Macro License

*This is the percentage of the 48 faculty respondents who provided this information.
** This is the percentage of the 174 practitioners who provided this information

\section{Faculty Reports of Availability of Graduate Macro Content in Their Program}

Fifty-seven percent $(n=119)$ of faculty respondents indicated that a macro concentration was currently available in their MSW program, and that their macro concentrations included content on administration and management (32.1\%), community organization (25.8\%), policy practice (20.6\%), international social development (6.7\%), and 'other' areas (5.7\%), which included social enterprise administration, planning, organizational development, and organizational change. Of the faculty respondents who were employed in social work programs that did not currently include a macro concentration, $70 \%(n=38)$ indicated that there was not currently any interest in creating a new concentration focused on macro practice.

Among faculty teaching in MSW programs that currently have macro concentrations, 81 faculty members responded to the question about whether or not their programs were growing, stable, or declining. Slightly more than half $(52 \%, n=42)$ of the 81 respondents indicated that enrollment in their macro concentration was stable, while $23 \%(n=19)$ indicated that enrollment was growing and the same number $(23 \%, n=19)$ that it was declining. Respondents pointed to marketing efforts that began with entering MSW students, flexible and diverse program options (including online MSW programs with a macro focus), and specialized concentrations (for example, human resources, public and nonprofit management, and social, economic, or international development) within the macro curriculum as key components to their programs' growth. Several respondents from all kinds of programs (growing/declining/stable) also mentioned the impact of dual degree programs, such as MSW/MPH or MSW/MPA, on their MSW macro concentrations. A few of the respondents saw the dual degrees as detracting from the macro concentrations; others saw them as an area of strength for their programs.

For programs that are declining in enrollment, open-ended responses referred to the impact of clinical licensure on curbing students' interest in macro education. Comments included "faculty are advising students that a clinical license will be critical for employment, even if the student aspires to a macro career" and "students seem very 
concerned about being able to get their license with an administration concentration.” Respondents also discussed market forces, lack of faculty trained in macro practice, lack of field placements with “...MSW agency supervision”, limited employment opportunities for macro practitioners, and "school's ambivalence" about a macro focus. Several respondents also indicated that macro faculty were retiring from their schools and were not being replaced.

\section{Faculty Perceptions of Student Attitudes Toward Macro Practice Education}

Faculty who indicated that their MSW programs included a macro concentration $(n=119)$ were asked to rate statements about their perceptions of the importance of various factors in students' selection of an area of emphasis in their MSW concentration-either clinical or macro. Each statement had a scale of 0 (not important) to 100 (very important). Of the 119 faculty who indicated that their MSW programs included a macro concentration, 109 completed the scale items.

\section{Table 2. Faculty Perceptions of Reasons Students Do Not Select Macro Concentration}

\begin{tabular}{lccc} 
& $\mathrm{n}$ & $\overline{\mathrm{x}}$ & $\sigma$ \\
\cline { 2 - 4 } Perceptions that there are fewer jobs available for macro & 74 & 72.1 & 28.23 \\
$\quad$ & & & \\
$\quad$ social workers & 74 & 70.7 & 26.59 \\
Advice from peers to select a clinical concentration & 73 & 68.0 & 28.00 \\
Licensing considerations & 71 & 63.2 & 30.70 \\
Advice from faculty to select a clinical concentration & 70 & 59.9 & 23.23 \\
$\begin{array}{l}\text { Confusion about what macro social work is } \\
\text { Perception that clinical social work is more lucrative than }\end{array} \quad$ & & 31.83 \\
$\quad$ macro social work & 70 & 54.9 & 30.71 \\
$\begin{array}{l}\text { Advice from foundation year field instructors to select a } \\
\quad \text { clinical concentration }\end{array}$ & 71 & 46.9 & 27.81 \\
$\quad$ Lack of role models & 69 & 45.3 & 27.42 \\
Fewer course options/electives in macro concentration & 68 & 43.9 & 27.62 \\
$\begin{array}{l}\text { Don't see a need for additional training in macro practice } \\
\text { Fewer field placement options in macro concentration }\end{array}$ & 66 & 37.0 & 27.96 \\
\hline
\end{tabular}

As presented in Table 2, the highest rated factors for student selection of concentrations included "perception that there are fewer jobs available for macro social workers" ( $\bar{x}=$ 72.1), "advice from peers to select a clinical concentration" ( $\bar{x}=70.7)$, and "licensing considerations" ( $\bar{x}=68)$. The lowest rated factors were "fewer field placement options in macro concentration" ( $\bar{x}=37.0)$ and "don't see a need for additional training in macro practice" $(\bar{x}=43.9)$. Although the standard deviations are fairly large, they do not change the overall interpretation of the responses. For example, for the first choice, "perception that there are fewer jobs available for macro social workers," the standard deviation was 28.23. This is a fairly wide range of responses; however, within one standard deviation, they are all still positive (i.e., higher than 50, the midpoint of the scale), indicating that although there was a wide range of responses, $68 \%$ of faculty agreed with the statement (Monette, Sullivan, DeJong, \& Hilton, 2014). 
Following their responses to the scale questions, over half of the respondents ( $\mathrm{n}=50$ of $\mathrm{n}=77$ ) provided an additional narrative comments. Several themes emerged from these responses including a lack of "role models" or examples of macro social workers, students coming into MSW programs with a clear clinical goal already determined, the mechanics of curriculum (i.e., selecting courses or tracks early in a program, the inability to move between or among concentrations, and/or the lack of macro content in the early parts of the MSW curriculum), and a perception that there are not adequate jobs for macro social workers. For example, one respondent stated, "If macro concepts are not interwoven with theory and practice; how will students understand what macro social work is or how it 'looks' in the real world. Similarly, how many faculty are involved in macro-level activities as part of their professional identities and how are they bringing it to their students? This isn't just about licensure. It's about us!” Another faculty respondent identified licensing concerns for many students, stating, "Desire to be a therapist rather than a social worker. Fear of not getting enough content in mental health diagnoses to pass licensing exams. Some states only license clinical social work."

Another theme that emerged was concern that there is a divide in social work education and practice around macro vs. micro practice. For example, one respondent stated: "First - 'macro' practice does not exist. We do ourselves a great disservice when we use a term that really has no meaning and just serves to further bifurcate us." Another stated, "My real concern is that we have a clinical/macro split. We need to integrate the theoretical underpinnings of our profession. This will involve supporting the overall consciousness development of social workers."

\section{Faculty Perceptions of Program Attitudes About Macro Curriculum}

Faculty respondents reflected on their MSW program's unconscious or conscious bias or preference for clinical or macro social work practice in its curriculum and approach. A five-item Likert-type scale was used, with responses ranging from 1 (strongly disagree) to 5 (strongly agree). The research team used SPSS to assess the reliability of the scale using Cronbach's alpha procedure for inter-item consistency. In doing so, the calculated Cronbach's alpha score came to .83; an alpha of .6 or higher demonstrates scale reliability (DeVellis, 2003). Faculty reported that students felt supported in their MSW macro concentration (59\% agreed or strongly agreed with this statement). They were almost evenly split (41\% strongly disagreed or disagreed; $45 \%$ agreed or strongly agreed) with the statement that students understood that macro social work practice is just as important as micro practice. However, faculty also supported (88\% agreed or strongly agreed) the statement that the majority of MSW students in their programs were interested in clinical practice, and 59\% agreed or strongly agreed with the statement that students felt there was an emphasis on clinical social work practice (see Table 3). 
Table 3. Faculty Perceptions of Student Attitudes Towards Macro Concentrations

\begin{tabular}{|c|c|c|c|c|c|}
\hline Scale Item & $\begin{array}{l}\text { Strongly } \\
\text { Disagree } \\
\mathrm{n}(\%) \\
\end{array}$ & $\begin{array}{c}\text { Disagree } \\
\text { n (\%) }\end{array}$ & $\begin{array}{l}\text { Neither } \\
\text { Agree nor } \\
\text { Disagree } \\
\text { n (\%) }\end{array}$ & $\begin{array}{c}\text { Agree } \\
\text { n (\%) }\end{array}$ & $\begin{array}{c}\text { Strongly } \\
\text { Agree } \\
\text { n (\%) }\end{array}$ \\
\hline $\begin{array}{l}\text { Students feel that our MSW program } \\
\text { is supportive of those who pursue a } \\
\text { macro concentration }\end{array}$ & $3(3.9)$ & $18(23.4)$ & 13 (16.9) & $25(32.5)$ & $18(23.4)$ \\
\hline $\begin{array}{l}\text { In our program, students understand } \\
\text { that macro social work is just as } \\
\text { important as micro (clinical or direct) } \\
\text { social work practice }\end{array}$ & $3(3.9)$ & 29 (37.7) & $10(13)$ & 22 (28.6) & $13(16.9)$ \\
\hline $\begin{array}{l}\text { In our program, students understand } \\
\text { that clinical social work is more } \\
\text { complex and needs more training } \\
\text { than macro social work practice. }\end{array}$ & $6(7.9)$ & 27 (35.5) & $23(30.3)$ & 17 (22.4) & $3(3.9)$ \\
\hline $\begin{array}{l}\text { The majority of the students in our } \\
\text { program are interested in clinical } \\
\text { social work. }\end{array}$ & $2(2.6)$ & $3(3.9)$ & $5(6.5)$ & 23 (29.9) & $44(57.1)$ \\
\hline $\begin{array}{l}\text { Students report that they feel there is } \\
\text { an emphasis on clinical social work } \\
\text { in our program. }\end{array}$ & $1(1.3)$ & 14 (18.2) & 16 (20.8) & $24(31.2)$ & $22(28.6)$ \\
\hline
\end{tabular}

Table 4. Macro Practitioner Experiences in their MSW program*

\begin{tabular}{lccccc}
\hline \multicolumn{1}{c}{ Scale Item } & $\begin{array}{c}\text { Strongly } \\
\text { Disagree } \\
\mathrm{n}(\%)\end{array}$ & $\begin{array}{c}\text { Disagree } \\
\mathrm{n}(\%)\end{array}$ & $\begin{array}{c}\text { Neither } \\
\text { Agree nor } \\
\text { Disagree } \\
\mathrm{n}(\%)\end{array}$ & $\begin{array}{c}\text { Agree } \\
\mathrm{n}(\%)\end{array}$ & $\begin{array}{c}\text { Strongly } \\
\text { Agree } \\
\mathrm{n}(\%)\end{array}$ \\
\hline $\begin{array}{l}\text { My program was supportive of } \\
\text { students who pursued a macro } \\
\text { concentration. }\end{array}$ & $5(2.6)$ & $10(5.2)$ & $14(7.3)$ & $71(37)$ & $92(47.9)$ \\
$\begin{array}{l}\text { I felt pressure from faculty or staff } \\
\text { to reconsider my choice of a } \\
\text { macro concentration. }\end{array}$ & $91(47.9)$ & $69(36.3)$ & $14(7.4)$ & $11(5.8)$ & $5(2.6)$ \\
$\begin{array}{l}\text { No one ever questioned my } \\
\text { decision to pursue a macro } \\
\text { concentration. }\end{array}$ & $9(4.7)$ & $35(18.4)$ & $12(6.3)$ & $53(27.9)$ & $81(42.6)$ \\
$\begin{array}{l}\text { In my program, I felt that macro } \\
\text { social work practice was just as } \\
\text { important as micro social work } \\
\text { practice. }\end{array}$ & $19(10)$ & $49(25.8)$ & $17(8.9)$ & $44(23.2)$ & $61(32.1)$ \\
$\begin{array}{l}\text { The majority of the students in my } \\
\text { program are interested in clinical } \\
\text { social work. }\end{array}$ & $11(5.8)$ & $11(5.8)$ & $13(6.8)$ & $51(26.8)$ & $104(54.7)$ \\
$\begin{array}{l}\text { There was an emphasis on clinical } \\
\text { social work in my program. }\end{array}$ & $12(6.3)$ & $23(12.1)$ & $44(23.2)$ & $63(33.2)$ & $48(25.3)$ \\
\hline *Note: $n$ 's vary due to variability in the number of responses to each item. & & \\
\hline
\end{tabular}




\section{Practitioners’ Recall of Attitudes About Macro Education}

Of 311 practitioners who responded to the items in this scale, $84 \%(n=249)$ indicated that their MSW programs offered a macro-focused concentration and $78 \%(n=194)$ indicated that they selected this concentration as their area of study. To assess their experience in their programs as macro students, researchers included a 6-item scale (see Table 4). Using SPSS, the research team calculated a Cronbach's alpha value of .82 for this scale.

When asked about their experiences as macro students in their MSW programs, practitioners reported that they felt supported within their programs (85\% either 'agreed' or 'strongly agreed' with this statement), and $71 \%$ agreed or strongly agreed that their decision to focus on macro social work practice was not questioned in their program. However, a smaller majority (55\%) agreed with the statement that macro social work was seen as equivalently important to micro social work, and $58 \%$ felt that there was an emphasis on clinical social work in their programs. Finally, eighty-two percent of respondents said the majority of students in their MSW programs were, indeed, focused on micro or clinical social work practice.

\section{Practitioner Recollection of MSW Program Bias and Support}

Narrative comments from practitioners reflected their varied experiences as macro concentration students. The majority were positive about their educational experience, with respondents mentioning "dedicated faculty" and a "committed cohort of other students" as key factors. Respondents also pointed to prior work experience as a reason for pursuing a macro concentration, and many indicated intentionally selecting programs that had a specialty in a specific area of macro practice such as administration, policy, or community organization.

Challenges identified by practitioners mirrored faculty's responses. They pointed to issues with finding field placements, accessing resources within their school including electives, and difficulties in finding macro employment after graduation. For example, one respondent stated, "the macro faculty was very supportive, but the program was given less emphasis and seemed like an afterthought." Another said: "The program itself was supportive, but in general macro students had less of a network, less access to professional resources, and fewer options for field placements with macro MSWs for supervisors.”

Another theme that emerged was students taking courses outside of a social work program in order to access macro coursework. One respondent said:

$75 \%$ of my classes were clinical students, there were very few macro field placement options, and macro concentration classes were limited, so I sought macro classes from the public policy school. My professors were very supportive of macro practice and studies, but the infrastructure did not encourage the macro path.

Similarly, another respondent commented: 
It was a legitimized program, but in order to get what I wanted I took as many classes as I could in other departments - like policy development and urban planning. The school did not see community organizing as a professional endeavor.

Finally, many respondents talked about feeling isolated or separated from a professional identity as social workers. For example, one respondent said: "Although my cohort believed in the importance of macro level social work, we acknowledged that non-macro level students sometimes did not completely think that what we were doing was legitimate social work." Another said: "The teachers...never discouraged anyone from pursuing macro work but it was also clear that they considered macro level work to be, somehow, separate from the rest of the profession.” Thus, although macro social work may have been part of the social work curriculum, some survey respondents did not feel integrated or connected with social work practice or its public mission.

\section{Discussion}

This exploratory study found that both macro practitioners and faculty reported a solid level of support for the inclusion of macro education in graduate social work programs. Faculty respondents reported experiencing strong support for macro-oriented curriculum, and approximately half reported that their macro concentrations were growing or stable. However, along with this perception of support, both faculty and practitioners also reported experiencing negative perceptions, attitudes, and experiences toward macro social work education in their MSW programs. Examples of barriers or challenges to macro education in their MSW programs included challenges in finding field placements that included a macro perspective, a lack of larger institutional support, and/or competition for relatively scarce resources with other concentrations, and students' concerns about employability as barriers to macro-focused MSW education. Finally, both the practitioners and the faculty reported that macro-oriented students were a minority in their MSW programs, regardless of the health of the macro concentration.

Practitioners reported that despite feeling support from faculty members for their area of focus, factors external to the curriculum of their MSW program, such as difficulty in finding macro-oriented field placements, institutional support for the concentration, and concerns about finding a job, challenged them in their macro educational experiences. Both practitioners and faculty remarked on the smaller numbers of macro-oriented students compared with the number of clinical students, and the impact this had both on students' experiences and on levels and quality of institutional support for macro students. Several also remarked that they had to go outside of the social work curriculum to access appropriate or adequate macro content, and many identified a sense of professional isolation from their more clinically-oriented classmates.

\section{External Influences on Social Work Curriculum}

The findings from this study support previous work that showed that there are factors external to the social work curriculum that impact macro social work education (Donaldson et al., 2014; Netting et al., 2016; Pritzker \& Applewhite, 2015; Reisch, 2015; Rothman, 
2012). These factors may include institutional demands within social work education, social work licensure, marketplace and professional demands, and macro social work identity development.

MSW programs are not immune to the challenges faced by institutions of higher education, such as enrollment, rising costs, and competing programs and opportunities. All of these concerns were reflected in our respondents' answers to the survey questions. For example, some faculty indicated that macro faculty positions were not filled upon retirement, or that there was a lack of access to institutional and community resources for macro faculty and students. Factors cited in previous research for the decline in macro social work enrollment and interest include a lack of support among other students, practicing social workers, and in some cases, field educators and faculty, for the pursuit of a macro concentration (Ezell et al., 2004), competition for field placements (Mor Barak et al., 2004; Rothman, 2012), and a belief that micro expertise should precede macro practice (Zippay \& Demone, 2011). Reported or perceived declines in students' interest in pursuing macro practice in social work may also be related to competition with other master's degrees in management, law, public health, or public policy (Ezell et al., 2004; Miller, Hopkins, \& Greif, 2008).

Concerns about the requirements and expectations of clinical licensure were mentioned by both faculty and practitioners in their survey responses, most typically in conjunction with concerns about employability of social workers without a clinical license. Contrary to the findings in some previous research, CSWE (2015b, 2016) data indicates that the proportion of macro social work graduates has remained stable over the past two decades. MSWs with a clinical license dominate the professional landscape (Donaldson et al., 2014). Although the variability in state licensing options and subsequent requirements influence this number (some states only offer a clinical license; Donaldson et al., 2014), the high rate of clinical licensure along with the movement of more proscriptive clinical content in social work courses raises questions as to whether licensing requirements influence social work curriculum, student choices, and perceived identity of graduate students.

Our results also indicate that there is concern about employment opportunities for macro-focused social workers, beyond worries about employability without a clinical license. Starr, Mizrahi, and Gurzinksy (1999) posited that students believe that a macro emphasis may be detrimental to their employment possibilities; our survey findings show that these perceptions about employment persist. Social workers who practice with larger systems are not always identified or well-represented within the profession (Lightfoot et al., 2016; Moore \& Johnston, 2002; Weiss, 2003, 2006), which can also lead to a lack of mentors and role models for new social workers, as well as a loss of the public identity of social workers as social change agents. Rothman (2012) reports that because licensing is geared toward clinical social work, "macro students feel that their employment options will be constrained because they will not be qualified to work in the much larger clinical arena if they are not able to get macro jobs or if they want to switch emphases” (p. 9).

In contrast, Pritzker and Applewhite (2015) found that macro social work graduates were able to successfully compete for administrative and policy positions with graduates from other related disciplines (for example, law, public administration, or public health) 
and that macro graduates reported higher salaries than the national average for all social workers. Thus, it is not evident that the demand for macro social workers is in fact weaker than for other types of social work practitioners. This leads us to wonder what other factors are shaping student, faculty, and practitioner perceptions -- including those cited by Rothman (2012), such as challenges in finding field placements, an emphasis on clinical practice within schools of social work, and licensure requirements. These are all areas in which we encourage further investigation and inquiry.

Both faculty and practitioner respondents reported that macro-oriented social workers often experience a sense of isolation from the larger social work profession and within the academy, both while they are pursuing their degrees and in the field. In addition to comparatively low enrollment numbers and licensure concerns, a lack of role models in practice settings and field placements contribute to this sense of isolation and are concerns in the education of macro social work practitioners (Mor Barak et al., 2004; Rothman, 2012).

Field education plays a critical role in orienting MSW students to various roles and opportunities in practice. Mizrahi and Dodd (2013) echo other researchers' calls for an increase in field placements that provide opportunities to "...fulfill the mission of social work in the real world" (p. 595). They go on to note that field experiences are among the most critical elements in shaping social work identity, a belief that is repeated in much of the literature (Mor Barak et al., 2004; Zippay \& Demone, 2011). Indeed, Han and Chow (2010) found that students who participated in macro level field placements in their second year of their MSW program were more likely to embrace a social-structural perspective of change. Macro field opportunities would allow new macro practitioners to practice the social work competencies identified by CSWE (2015a), as well as provide them with role models and mentors as they move into practice in an increasingly complex professional sphere. Thus, the continuing issues in finding macro social work field placements have implications for educating the skilled social workers who are needed to respond to the demands of the social environment (Reisch, 2015).

\section{Macro Social Workers’ Identity Development}

There is an ongoing need for macro social workers to develop a sense of professional identity and connection with the profession in order for this area of practice and education to thrive (Hill et al., 2010; Lightfoot et al., 2016). Some of our participants pointed out that many of the employment opportunities for macro social workers do not specifically require a social work degree or a social work license. Indeed, many people with an MSW may be working as analysts, researchers, or administrators, and may not be calling themselves social workers. This lack of public identification as a social worker disadvantages the profession in that it: a) lowers the visibility and perception of social workers as a good fit for this type of work, b) disadvantages new practitioners and students as they do not see role models and mentors in the profession in the same way that micro social workers do, and c) handicaps social work educators because it makes finding and sustaining field placements and other 'real world' learning opportunities particularly difficult. 
Given the disadvantages stemming from the lack of public identification of macro practitioners, there are several easy strategies that can be used to promote macro social work. Faculty who teach macro social work can urge graduating students to continue to make their social work identity visible in workplaces and other settings to help broaden the perception of social workers as community organizers, policy analysts, program administrators, and other macro change agents. In addition, promoting macro social work associations (Hill et al., 2010), macro social work conferences and professional development opportunities specific to macro social work might assist macro practitioners see the value of social work-connected training and networking. Professional social work associations, like NASW, must be prepared to respond to this demand as they have a role in shaping the public perception of social work. Finally, many states link Title Protection for social workers to licensing status rather than degree earned. As mentioned above, few states offer an advanced macro license and most macro employment opportunities do not require licensure. As a result, the title protection laws may discourage macro social workers from pro-actively identifying as social workers to remain compliant with state laws about who can call her/himself a social worker. Therefore, modifying state laws to link title protection to professional degree rather than license may open the door for macro social workers who are not licensed to reclaim their identity as social workers.

\section{Study Limitations}

The sampling approach was taken to reach as wide an audience as possible via an online survey. However, due to the wide range of diversity in social work licensing in the U.S., finding universally accepted language regarding state licensing requirements was a barrier. For example, exams do not include a macro option, but many practitioners mistake the Advanced Generalist exam and title for a macro exam and credential. State agencies who provide the licensing also vary between states. There are also, anecdotally, many macro practitioners who no longer identify as social workers, and locating them was difficult.

Concern about macro social work education and practice has implications for international social work. Macro social work practice is essential in international contexts where social workers are engaged in infrastructure development, capacity building, peace building, and human rights practice. Nevertheless, this manuscript remains largely focused on the U.S. context and we recognize that additional work is needed to further understand the impact of macro social work education on the preparation of social workers for international practice contexts.

For reasons unknown to us, not all participants completed the entire survey. This is common in survey research, but, at times, these omissions made it difficult to draw conclusions in our understanding of the issues. Additionally, future researchers would be well-served to explore in more detail the impact of the faculty role whether full or parttime- on their perceptions and experiences of the macro social work curriculum. Finally, the intent and design of this study was exploratory; it was not intended to demonstrate causality or yield broadly generalizable findings (Monette et al., 2014). Instead, the researchers' intent was to further explore the perceptions of both faculty and practitioners about the intersections of the social work environment (including, but not limited to 
licensure, professional regulation, identity, academic experience and institutional support) and social work graduate education for macro practitioners.

\section{Conclusion}

Social work's professional identity and theoretical perspectives are rooted in ".... dual focus on individual and social change both in the United States and internationally" (Mizrahi \& Dodd, 2013, p. 580). However, given the increasing emphasis on clinical interventions, the question arises as to whether social work education, as it currently stands, is imparting the full mission of social work as it is historically defined (D'Aprix, Dunlap, Abel, \& Edwards, 2004). Or, are social work programs being unduly influenced by social forces that have caused a slow but growing emphasis on clinical social work? Reisch (2015) calls for a reintegration and refocus on macro practice in social work, in order to respond to the increasing need to honor our "...commitment to social justice and human dignity” (p.14). In our current social and political environments, there is clearly a need for social workers who are thinking, planning, and acting to address large system challenges.

Evidence of strengthening and advancing macro practice in MSW programs would be program efforts to redress many of the imbalances described in this study. This includes offering a range of macro field placements and electives for macro students; ensuring that faculty who teach macro practice courses are experienced in those areas; creating a program culture where all forms of social work practice are equally valued; educating parttime faculty and field instructors about the importance and value of macro practice; and ensuring that generalist social work education includes equal educational and field experiences in micro, mezzo, and macro practice. CSWE has affirmed the Special Commission goal to have $20 \%$ of social work students across the country enrolled in macro concentrations by the year 2020, otherwise known as 20 by 2020 (Special Commission to Advance Macro Practice in Social Work, 2017). The challenge is to implement this goal in Schools of Social Work.

While attempting to strengthen the macro practice areas of social work education, one must be cautious about contributing to the bifurcation of the profession, and the micromacro divide expressed by some of the participants in this study. Efforts by the Special Commission to Advance Macro Practice and others who have been concerned about the erosion of macro curricula and specializations in social work programs seek to ensure that all social workers are prepared to engage in the full range of practice in which our profession is historically grounded and remains contemporarily mandated through the NASW (2017) Code of Ethics. At the same time, social work programs must provide specialized educational options for social work students who desire to work full-time in policy practice, community practice, administration, or international social development. The complexity of issues that social work clients face locally, nationally, and globally compel us to echo these calls for a refocus on the integration of macro practice content and the strengthening of macro practice specializations. It also challenges our colleagues to continue to wrestle with the questions and concerns raised in this study and in previous literature regarding the importance of macro practice skills and knowledge for social work practice. 
As we enter an era where the basic protections of human rights (e.g., health care, voting, access to free public education, freedom from discrimination) and protections to the environment are being eroded, the social work profession's presence as community organizers and policy practitioners is urgent. In fact, addressing these challenges provide an opportunity for micro and macro social workers to work together to forge new partnerships so that the profession can provide bold leadership at national, state, and local levels. We are a profession that is rooted in the person-in-environment and have-a range of models and frameworks that address the multi-systems challenges our clients, customers, and consumers are facing today. Social work, united by our values and Code of Ethics, must be an integral part of dismantling systems of oppression and building environments that lift up the dignity of all people and help reweave the fabric of our communities.

\section{References}

Association for Community Organization and Social Administration. (2017). About the special commission. Retrieved from https://www.acosa.org/joomla/about-the-specialcommission

Bibus, A., \& Boutté-Queen, N. (2011). Regulating Social Work: A primer on licensing practice. Chicago, IL: Lyceum.

Biggerstaff, M. A. (2000). A critique of the Model State Social Work Practice Act. Social Work, 45(2), 105-115. doi: https://doi.org/10.1093/sw/45.2.105

Black, P. N., \& Whelley, J. (1999). The social work licensure exam: Examining the exam through the lens of CSWE curriculum policy. Areté, 23, 66-76.

Boutte'-Queen, N. M. (2003). Identifying barriers to obtaining social work licensure (Order No. 3103583). Available from ProQuest Dissertations \& Theses Global (305327209). Retrieved from http://proxycu.wrlc.org/login?url=https://searchproquest-com.proxycu.wrlc.org/docview/305327209?accountid=9940

Cherry, A., Rothman, B., \& Skolnik, L. (1989). Licensure as a dilemma for social work education: Findings of a national study. Journal of Social Work Education, 25(3), 268-275.

Council on Social Work Education [CSWE]. (2015a). Educational Policy and Accreditation Standards. Alexandria, VA: Author.

CSWE. (2015b). 2014 statistics on social work education in the United States. Alexandria, VA: Author.

CSWE. (2016). Annual statistics on social work education in the United States: 2015. Alexandria, VA: Author.

D’Aprix, A., Dunlap, K., Abel, E., \& Edwards, R. (2004). Goodness of fit: Career goals of MSW students and the aims of the social work profession in the United States. Social Work Education, 23(3), 265-280. doi: https://doi.org/10.1080/0261547042000224029 
DeVellis, R. F. (2003). Scale development: Theory and applications. Newbury Park, NJ: Sage.

Donaldson, L. P., Fogel, S. J., Hill, K., Erickson, C., \& Ferguson, S. (2016). Attitudes toward advanced licensing for macro social work practice. Journal of Community Practice, 24(1), 77-93. doi: https://doi.org/10.1080/10705422.2015.1127864

Donaldson, L. P., Hill, K., Ferguson, S., Fogel, S. J., \& Erickson, C. (2014). Contemporary social work licensure: Implications for macro social work practice and education. Social Work, 59(1), 52-61. doi: https://doi.org/10.1093/sw/swt045

Ezell, M., Chernesky, R., \& Healy, L. (2004). The learning climate for administration students. Administration in Social Work, 28(1), 57-76. doi: https://doi.org/10.1300/J147v28n01_05

Fisher, R., \& Corciullo, D. (2011). Rebuilding community organizing education in social work. Journal of Community Practice, 19(4), 355-368. doi: https://doi.org/10.1080/10705422.2011.625537

Fogel, S. J., \& Ersing, R. (2016). Macro focused social work dissertations: A preliminary look at the numbers. Journal of Social Work Education, 52(2), 170-177.

Gibelman, M. (1999). The search for identity: Defining social work - Past, present, future. Social Work, 44(4), 298-310. doi: https://doi.org/10.1093/sw/44.4.298

Han, M., \& Chow, J. C. (2010). What changes MSW students' view on the mission of social work? Social Work Education: The International Journal, 29(2), 205-221. doi: https://doi.org/10.1080/02615470902912227

Hill, K., Ferguson, S., \& Erickson, C. (2010). Sustaining and strengthening a macro identity: The Association of Macro Practice Social Work. Journal of Community Practice, 18(4), 513-527. doi: https://doi.org/10.1080/10705422.2010.519684

Kleiner, M. M., \& Krueger, A. B. (2008). The prevalence and effects of occupational licensing. (Working paper 14308). Retrieved from National Bureau of Economic Research website http://nber.org/papers/w14308

Lein, L., Uehara, E. S., Lightfoot, E., Lawlor, E. F., \& Williams, J. H. (2017). A collaborative framework for envision the future of social work research and education. Social Work Research, 41(2), 67-71. doi: https://doi.org/10.1093/swr/svx008

Lightfoot, E., Nienow, M., Moua, K. N., Colburn, G., \& Petri, A. (2016). Insights on professional identification and licensure from community practice social workers. Journal of Community Practice, 24(2), 123-146. doi: https://doi.org/10.1080/10705422.2016.1165328

Lubove, R. (1977). The professional altruist: The emergence of social work as a career 1880-1930. New York: Athenaeum.

Miller, J. J., Deck, S. M., Grise-Owens, R., \& Borders, K. (2015). Exploring graduate students' perceptions about social work licensing. Social Work Education: The 
International Journal, 34(8), 986-1004. doi:

https://doi.org/10.1080/02615479.2015.1096924

Miller, J. J., Grise-Owens, E., \& Escobar-Ratliff, L. (2015). Preparing MSW students for social work licensure: A curricular case example. Journal of Teaching in Social Work, 35(3), 296-316. doi: https://doi.org/10.1080/08841233.2015.1039160

Miller, S., Hopkins, K., \& Greif, G. (2008). Dual degree social work programs: Where are the programs and where are the graduates? Advances in Social Work, 9(1), 21-43.

Miller, S., Tice, C., \& Hall, D. (2008). The generalist model: Where do macro and micro converge? Advances in Social Work, 9(2), 79-90.

Mizrahi, T., \& Dodd, S. (2013). MSW students' perspectives on social work goals and social activism before and after completing graduate education. Journal of Social Work Education, 49(4), 580-600.

Monette, D., Sullivan, T., DeJong, C., \& Hilton, T. (2014). Applied social research: A tool for the human services $\left(9^{\text {th }}\right.$ ed.). Belmont, CA: Brooks/Cole.

Moore, L. S., \& Johnston, L. B. (2002). Involving students in political advocacy and social change. Journal of Community Practice, 10(2), 89-101. doi:

https://doi.org/10.1300/J125v10n02_06

Mor Barak, M., Travis, D., \& Bess, G. (2004). Exploring managers and administrator’s retrospective perceptions of their field work experience: A national study.

Administration in Social Work, 28(1), 21-44. doi:

https://doi.org/10.1300/J147v28n01_03

National Association of Social Work. (2017). Code of ethics. Washington, D.C.: Author.

Netting, F. E., O’Connor, M. K., Cole, P. L., Hopkins, K., Jones, J. L., Kim, Y... Wike, T. (2016). Reclaiming and reimagining macro social work education: A collective biography. Journal of Social Work Education, 52(2), 157-169.

Pine, A. B., \& Healy, L. M. (1994). Is state licensing an obstacle to social work students' section of macro practice as a specialization? Yes! In M. J. Austin \& J. I. Lowe (Eds.), Controversial issues in communities and organizations (pp. 268-273). Needham Heights, MA: Allyn \& Bacon.

Pritzker, S., \& Applewhite, S. (2015). Going ‘Macro’: Exploring the careers of macro practitioners. Social Work, 60(3), 191-199. doi: https://doi.org/10.1093/sw/swv019

Reisch, M. (2015). Why macro practice matters. Special Commission to Advance Macro Practice in Social Work. Retrieved from http://files.ctctcdn.com/de9b9b0e001/89cf81d7-bd9e-428a-9209-961f388daa8d.pdf

Rothman, J. (2012). Education for macro intervention: A survey of problems and prospects. Chicago, IL: Association for Community Organization and Social Administration.

Rothman, J., \& Mizrahi, T. (2014). Balancing micro and macro practice: A challenge for social work. Social Work, 59(1), 91-93. doi: https://doi.org/10.1093/sw/swt067 
Schneider, R., \& Netting, F. E. (1999). Influencing state policy in a time of devolution: Upholding social work's great tradition. Social Work, 44(4), 349-357. doi: https://doi.org/10.1093/sw/44.4.349

Specht, H., \& Courtney, M. (1994). Unfaithful angels: How social work has abandoned its mission. New York, NY: Free Press.

Special Commission to Advance Macro Practice in Social Work (2017). It's time macro matters! Retrieved from https://www.acosa.org/joomla/special-commission-resources

Starr, R., Mizrahi, T., \& Gurzinsky, E. (1999). Where have all the organizers gone? The career paths of community organizing social work alumni. Journal of Community Practice, 63(3), 23-48. doi: https://doi.org/10.1300/J125v06n03 02

Strom, K., \& Gingerich, W. (1993). Educating students for the new market realities. Journal of Social Work Education, 29(1), 78-87.

Weiss, I. (2003). Social work students and social change: On the link between views on poverty, social work goals, and policy practice. International Journal of Social Welfare, 12(2), 132-141. doi: https://doi.org/10.1111/1468-2397.00251

Weiss, I. (2006). Modes of practice and the dual mission of social work. Journal of Social Service Research, 32(3), 135-151. doi: https://doi.org/10.1300/J079v32n03_08

Wenocur, S., \& Reisch, M. (1989). From charity to enterprise: The development of American social work in a market economy. University of Chicago Press: Chicago and Urbana, IL.

Wermeling, L., Hunn, V., \& McLendon, T. (2013). Social work education's effect on retention. Journal of Social Work Education, 49(2), 222-234.

Zippay, A., \& Demone, H. (2011). Initial macro-level job responsibilities among MSW graduates. Administration in Social Work, 35(4), 412-424. doi: https://doi.org/10.1080/03643107.2011.599301

Author note: Address correspondence to: Katharine Hill, PhD St. Catherine University and University of St. Thomas School of Social Work, 2115 Summit Avenue, SCB \#201, St. Paul, MN 55105. Katharine.hill@stthomas.edu

Acknowledgements: The authors wish to acknowledge the support of the New York Community Trust for this project. 